\title{
HOW RELATIONSHIPS IMPACT SENSE OF BELONGING IN SCHOOLS AMONGST FEMALE ADOLESCENTS FROM REFUGEE BACKGROUNDS
}

\author{
Sonja Aicha Van Der Putten \\ Faculty of Education, Simon Fraser University (Canada)
}

\begin{abstract}
Education is believed to play an essential role in creating a sense of belonging amongst adolescents from refugee backgrounds. This narrative inquiry study set out to better understand the influence that relationships formed in one Canadian school community played in the development of a sense of belonging amongst female adolescent students from refugee backgrounds. Study participants were from Middle Eastern and East African origin and had been living in Canada for two-years or less. Data were collected over a five-month period through two sets of interviews, and a series of observations. Findings indicated the students from refugee backgrounds sense of belonging in school was strengthened by strong relationships with teachers from whom they perceived a genuine sense of support and care, which resulted in higher academic achievement. The study also conveyed that students felt that their Canadian-born peers largely ignored them in class, which resulted in increased feelings of social isolation and lack of belonging. The female student experience was further influenced by additional familial obligations and responsibilities.
\end{abstract}

Keywords: Refugees, education, belonging, females, students.

\section{Introduction}

Children and adolescents under the age of 18 years old make up over half of all individuals from refugee backgrounds worldwide (Children, n.d.). These children and adolescents have endured untold hardships, and the risk of abuse, neglect, violence, exploitation, trafficking or military recruitment, does not end upon resettlement (Children, n.d.). Host countries have a responsibility to consider the unique cognitive, social and emotional needs of developing children and adolescents being resettled in their communities, and one way to do so is through education (UNHCR, 2015). Education acts as a stabilizing force in the lives of children and adolescents from refugee backgrounds by protecting them from recruitment into armed groups, sexual exploitation and child marriage; by creating community resilience; by empowering them with the skills and knowledge necessary to live meaningful lives; and by enlightening them to learn about themselves and the world they live in (Education, n.d.).

This study set out to investigate the impact school communities play on adolescents from refugee backgrounds' sense of belonging. This research examined three fundamental questions. First, the study analyzed what it meant for female adolescent students from refugee backgrounds to experience a sense of belonging in their school (SOBIS). Second, it explored the impact of teacher and peer relationships on student sense of belonging; and third it sought to answer how the services available in one Canadian secondary school system influenced student sense of belonging.

Education plays an essential role in creating a sense of belonging and preserving hope amongst adolescents from refugee backgrounds (Hoot, 2011). To feel a sense of belonging in school (SOBIS) is to feel connected to a particular group, to feel accepted by peers, supported by teachers and to feel supported by the school community (2015). Students' sense of belonging is determined by their level of attachment to their school, their compliance with school rules and expectations, their involvement in academics and extracurricular activities, and their belief in the values of their school (Kia-Keating and Ellis, 2007). A strong sense of belonging is related to positive academic, behavioural and psychological outcomes, including improved self-efficacy, motivation and reduced social-emotional distress (Kia-Keating and Ellis, 2007).

This study conveyed that students from refugee backgrounds are not just an addition to the school, but rather are a part of the school community. Yet, to truly feel a sense of belonging within a school community, efforts should be made, both by the schools and communities, as well as by the newcomers 
themselves. Students from refugee backgrounds were genuinely happy to arrive at school, excited to commence their learning, or pick up where they left off in their academic studies. The study participants showed great determination and effort in their learning, and conveyed a strong sense of hope that their Canadian education could help improve the lives of themselves and their families. The stronger relationships they were able to develop with their teachers and peers, the greater sense of belonging they felt. However, barriers posed by language skills, poverty, mental health and gendered expectations, were a constant source of challenge in their lives.

\section{Method}

\subsection{Participants}

Study participants were chosen through a selective or purposive sampling process, which narrows down the participants to a select group of people who fit a particular profile (Connelly \& Clandinin, 1999). In consultation with the English Language Learner teachers, participants were selected who were female, from refugee backgrounds, have been in Canada two years or less and who maintained a working knowledge of the English language.

Females were chosen as focal participants in this study because female adolescents from refugee backgrounds often have different experiences both during conflict and post-conflict than their male counterparts. During times of conflict, female and male children and adolescents who are directly involved in the conflict (often through deliberate strategic targeting), have many different experiences, ranging from sexual violence, to economic exploitation, to forced recruitment as combatants (Women's Commission for Refugee Women and Children, 2000). The study uses narrative inquiry to focus specifically on female adolescents and to give voice to their unique experiences.

\subsection{Research design}

This study collected data from student participants and English language learner (ELL) teacher interviews, classroom and school community observations, and a field note journal. Students were interviewed to allow them the opportunity to explain their stories in their own voices. ELL teachers were interviewed to better understand the influence of the classroom community on the student participants' experiences of belonging. Interviews were semi-structured and were guided by a set of general questions related to the study's core sense of belonging questions (Merriam \& Tisdell, 2016).

Observations were conducted to better understand the influence of the school community on students' sense of belonging. Observations allowed the researcher to record first-hand accounts of participant experiences in their classrooms, in the wider school community (e.g. school performances and events), at relevant meetings, on the sports-field and at club gatherings. Observations also allowed the researcher to observe the students in a variety of school community settings. Field notes were recorded from these observations in a field note journal in which the researcher used description, quotations and comments to describe situations.

The study took place at a large inter-city Secondary school located in a sub-urban neighbourhood in a large metropolitan community in British Columbia, Canada. The student population intermixes with the reality of the high levels of poverty, criminal activity, and opioid usage in this neighbourhood daily.

The stories being shared throughout this narrative inquiry were those of changing identities and the discovery of the self, as the participants evolved and matured, as adolescents, as students, as young women and as new Canadians. The stories they share link together different parts of their lives, public and private, and connect their pasts to their futures, shaping a story about who they are (Connelly \& Clandinin, 1999, p. 5).

\subsection{Data analysis}

The data analysis for this study involved collected, coding (both open and axial), and organizing data into themes. From these themes, categories are then created which represented the data and formed an interpretation of them (Creswell, 2011, p. 179). Concepts were identified, labelled, and categories were created based on the similarities and differences, as well as patterns and structures, amongst concepts (Basit, 2003).

To begin the analysis, open coding was applied to the first set of interviews and observations. Once all the raw data had been collected from the first round of interviews, and observations, a second interview was held. Upon completion of the second phase of data collection the new quotes, comments, notes and stories were again coded, and applied to the categories that had emerged in the first round of data collection - where relevant. A new document with new categories based on the study's core questions was created, from which the process of axial coding commenced, and an attempt to relate the main codes to each other, and to the core questions being asked was made (Creswell, 2011, p.184). The first two rounds 
of data were used to sort into the core question categories. The data was then divided into naturally emerging thematically based categories, core question categories and outliers, which were data that did not seem to fit in any category. Finally, codes, categories and core questions, were sorted and compared, to look for themes and patterns, a third time, in an attempt to make better sense of them.

Throughout the narrative inquiry process, the researcher employed reflection and reflexivity as important elements of the process which help to keep in check bias perspectives and assumptions (Marshall \& Reason, 2008). Guarding against personal bias was further reinforced by the development of categories that were supported by multiple pieces of data that shared similar themes, and were not just bits and pieces of information. Furthermore, participants were frequently consulted with that their voices were being expressed accurately and that the analysis and theories that emerged were consistent with their views and experiences. Participants were asked to read over their interviews, and to expand upon certain situations that had arisen during the observation periods, both in and around the school community.

\subsection{The impact of positive relationships on sense of belonging in school (SOBIS)}

Students from refugee backgrounds SOBIS was strengthened by strong and positive relationships with teachers from whom they perceived a genuine sense of support and care (Demanet \& Van Houtte, 2012; Hattie \& Anderman, 2013; Hoot, 2011; Wentzel, 1998). Study participants explained that teachers who asked them about their day, inquired if they looked unwell or simply greeted them upon arriving to class, were "nicer" than other teachers. "Nicer" teachers were perceived as being easier to talk to, kinder and more accepting. The study found that in classrooms where the students perceived their teacher as being kind and helpful, the study participants were better able to self-advocate and seek out help when they needed it in their learning. Their sense of belonging was developed as being part of a learning community, in which questions were encouraged and mistakes inevitable, as opposed to being the one isolated student who did not understand the lesson. These students did better academically in supportive teachers' classes. Unfortunately, the study participants identified on average only three teachers (of the eight-to-ten they may learn from in any given year), with whom they felt a supportive relationship. These teachers were generally the Learning Support or English Language Learner (ELL) teacher and one or two other specific teachers in the entire school, which the study participants identified as being supportive. ELL teacher Priya conveys the desire she has to get to know her students on an individual level, but the frustrations that emerge in simply trying to connect with students and their families.

Getting to know the students' backgrounds and knowing they're refugees, I wanted to know more about them...I often wish I could just pick up the phone and call [parents] but we always need multicultural workers and sometimes it takes weeks for them to get back to me...I wish we had a multicultural worker in the school who was always around...we need translators...before we can have a dialogue to get to the point of [even a simple] situation.

(Priya, Interview I, April 4, 2017)

In addition, adolescents' attitudes, choices of activities and emotional well-being are closely linked to that of their peer groups, and sense of belonging largely depends on the acceptance attained by peer groups (Brown \& Larson, 2009). The study participants from families that provided the most support and encouragement for them to explore their new communities, were more involved in the school and wider community, and generally had more friends and acquaintances outside the ELL classroom. Furthermore, their level of English was stronger than that of their newcomer peers, which can be attributed to more time spent with native English speakers through the clubs, teams, organizations and jobs in which they participated. The study also conveyed that students felt that their Canadian-born peers largely ignored them in class discussions, in group work and in the hallways. They believed this to be a related to their language abilities and the fact that their peers had difficulty understanding them. As a result, study participants were more reluctant to speak up in class and often withheld their opinions for fear of their peers whispering about them, even if only to clarify what they had to say.

\section{Conclusion}

In the secondary setting, sense of belonging is not so straightforward for newcomer or Canadian-born students alike either. Constantly shifting and changing senses of identity and self-concept amongst all adolescents, convey that many students in the secondary school settings, whether newcomer or Canadian-born, do not feel a strong connection to, or belonging in, their high school generally (Connelly \& Clandinin, 1999, p. 94). Adolescence poses developmental and social challenges regardless of background, ethnicity and personality. Future studies that compare the level of sense of belonging amongst Canadian-born students to the level of sense of belonging experienced by students from refugee 
backgrounds would provide greater insight into our general understanding of the development of adolescent students' SOBIS.

Connecting and Acceptance: Whether students from refugee backgrounds develop a sense of belonging in school depends on how connected and accepted they feel in their school. This is conveyed by how welcoming the school is to them as demonstrated by the closeness of the relationships they form with their teachers and peers, and the supports that are available to help them achieve success in their school. The daily stressors that continue in the lives of students from refugee backgrounds after their arrival to their new country are persistent. Poverty, low language skills, disjointed families, and mental health concerns, all contribute to poor academic achievement and social isolation, requiring students from refugee backgrounds to have a great deal of stamina and endurance to persevere. While getting involved and actively contributing to the school and community environment are proactive measures that students from refugee backgrounds can take to start to build trusting relationships with teachers and peers, females are further challenged with gendered expectations in their homes that may pose barriers to their school and community participation.

Continued Challenges: The challenges faced by students and families of refugee backgrounds do not stop upon their arrival in their host country, and Canada is no exception. The study participants made frequent comments throughout the interviews about the high cost of living in Canada, including the cost of food, transportation and housing. Addressing ways to better support families financially as well as providing them with skills and language training, would enable parents to better care for their children and alleviate much of the stress on their children.

\section{Study significance}

Schools and communities that are able to foster a positive sense of belonging amongst students from refugee backgrounds increase their pro-social outcomes and decrease their negative well-being outcomes. The positive academic, behavioural and psychological outcomes of students who feel a strong sense of SOBIS, results in improved self-efficacy, motivation and reduced social-emotional distress (Kia-Keating and Ellis, 2007). However, in order for this to occur, skills and language training, affordable housing, increased minimum wages to reflect the cost of living and affordable day-care, is required to better support families and subsequently students from refugee backgrounds. Presently, Canada does not spend enough money on language services, skills accreditation and on training for newcomers (Grubel \& Grady, 2011). The Canadian government could significantly reduce the costs to taxpayers of paying for social services and welfare programs of newcomers, if they were to put in place the proper training and resources to better support these families upon arrival to Canada (Grubel \& Grady, 2011). Future studies would benefit from examining the provision of more equitable support for students from refugee backgrounds. Many students stated that they felt treated unfairly because they believed themselves to be working equally as hard or harder than their peers, yet their grades were not reflective of their efforts. A future study which examines how to provide equitable access to opportunities, such as post-secondary education, while recognizing practical limitations such as language barriers, knowledge gaps (from interrupted educations), and financial barriers, is required to help students feel that their new society is supportive and a fair one that they want to positively contribute to.

Children and adolescents from refugee backgrounds are ordinary people, who have been met with extraordinary circumstances. They are capable of enhancing and strengthening the social fabric of our society, and as we continue to welcome thousands of people from refugee backgrounds to Canada annually, we have a responsibility to commit to helping support them upon arrival and throughout the settlement process, both for their well-being and for the health of our society.

\section{References}

Anderman, E. M. (2002). School effects on psychological outcomes during adolescence. Journal of educational psychology, 94(4), 795-797.

Basit, T. (2003). Manual or electronic? The role of coding in qualitative data analysis. Educational research, 45(2), 143-154.

Brown, B. B., \& Larson, J. (2009). Peer relationships in adolescence. In Brown, B.B. \& Larson, J. (Eds.), The Handbook of adolescent psychology (74-100). USA: Wiley Online Library.

Children. (n.d.). United Nations High Commissioner on Refugees. Retrieved September $28^{\text {th }}$ n.d., from https://www.unhcr.org/children-49c3646c1e8.html

Clandinin, D. J., \& Connelly, F. M. (1996). Teacher's professional knowledge landscapes: Teacher stories - stories of teachers - school stories - stories of schools. Educational Researcher, 25(3), 24-30. 
Connelly, M. F., \& Clandinin, J. D. (1999). Shaping a professional identity: Stories of educational practice. New York, USA: Teachers College Press.

Convention on the Rights of the Child. (2015, August 18), United Nations Human Rights Office of the High Commissioner. $\quad$ Retrieved September $28^{\text {th }}, \quad$ n.d. from http://www.ohchr.org/en/professionalinterest/pages/crc.aspx

Creswell, J. W. (2011). Educational research: Planning, conducting, and evaluating quantitative and qualitative research (4th $e d$.). NC, USA: Merrill.

Demanet, J., \& Van Houtte, M. (2012). School belonging and school misconduct: The differing role of teacher and peer attachment. Journal of Youth and Adolescence, 41(4), 499-514.

Education. (n.d.). United Nations High Commissioner on Refugees. Retrieved September $28^{\text {th }}$ n.d., from https://www.unhcr.org/education.html

Ferede, M. K. (2012). Structural factors associated with higher education access for first-generation refugees in Canada: An agenda for research. Refuge: Canada's Journal on Refugees, 27(2), 79-88.

Figures at a Glance. (2019). United Nations High Commissioner on Refugees. Retrieved September $28^{\text {th }}$ n.d., from https://www.unhcr.org/ph/figures-at-a-glance

Frater-Mathieson, K. (2004). Resilience. In R. Hamilton \& D. Moore (Eds.), Educational Interventions for Refugee Children (53-63). London, UK: Routledge Falmer Publishers.

Grubel, H. \& Grady, P. (2011). Immigration and the Canadian Welfare State. The Fraser Institute. Retrieved from https://www.fraserinstitute.org/sites/default/files/immigration-and-the-canadianwelfare-state-2011.pdf

Guo, Y., Maitra, S., \& Guo, S. (2019). "I belong to nowhere": Syrian refugee children's perspectives on school integration. Journal of Contemporary Issues in Education, 14(1), 89-105.

Hattie, J., \& Anderman, E. M. (2013). Introduction. In J. Hattie, \& E.M. Anderman, (Eds.), International Guide to Student Achievement (xix-xxii). NY, USA: Routledge.

Hoot, J. L. (2011). Working with very young refugee children in our schools: Implications for the world's teachers. Procedia-Social and Behavioral Sciences, 15, 1751-1755.

Kia-Keating, M., \& Ellis, B. H. (2007). Belonging and Connection to School in Resettlement: Young Refugees, School Belonging, and Psychosocial Adjustment. Clinical Child Psychology and Psychiatry, 12(1), 29-43.

Libbey, H. P. (2007). School connectedness: Influence above and beyond family connectedness. (Published doctoral dissertation). University of Minnesota, MN, USA.

Marshall, J., \& Reason, P. (2008). Taking an attitude of inquiry. Towards quality improvement of action research: Developing ethics and standards, 61-82.

Merriam, S., \& Tisdell, E. (2016). Qualitative research: A guide to design and implementation (4th ed.). San Francisco, USA: Jossey-Bass.

Qin-Hilliard, D. B. (2003). Gendered Expectations and Gendered Experiences: Immigrant Students' Adaptation in Schools. New Directions for Student Leadership, 2003(100), 91-109.

Wentzel, K.R. (1998). Social Relationships and Motivation in Middle School: The Role of Parents, Teachers, and Peers. Journal of Educational Psychology, 90(2), 202-209

Women's Commission for Refugee Women \& Children. (2000, January 1). Untapped Potential: Adolescents Affected by Armed Conflict. United Nations International Children's Emergency Fund. Retrieved from http://www.unicef.org/emerg/files/adolescents_armed_conflict.pdf 